\title{
DSG3 wt Allele
}

National Cancer Institute

\section{Source}

National Cancer Institute. DSG3 wt Allele. NCI Thesaurus. Code C101149.

Human DSG3 wild-type allele is located in the vicinity of $18 q 12.1$ and is approximately 31

$\mathrm{kb}$ in length. This allele, which encodes desmoglein-3 protein, is involved in the modulation of cell-cell adhesion. 